\title{
Indledning \\ Der går et kulturfundamentalistisk spøgelse gennem Europa
}

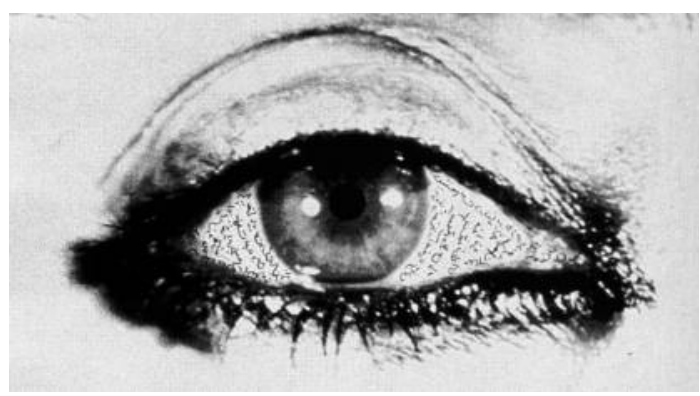

Shirin Neshat, "Offered Eyes” (udsnit), 1993

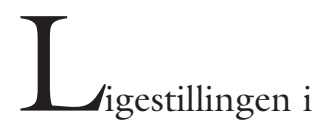

det danske samfund anno 2000 handler ikke længere kun om den kønsmæssige ligestilling. I manglen på accept af det flerkulturelle og fler-religiøse Danmark, findes de ulige magtrelationer i langt højere grad indenfor etnicitet, i adgangen til arbejdsmarkedet, i spørgsmål om uddannelse. Måske handler ligestilling i dag i højere grad om at udbygge medborgerskabet, og derved styrke og højne retssikkerheden for indvandrere og flygtninge.

Dette temanummer af Kvinder, Kon \& Forskning handler om islam, orientalisme og kulturmøder set i et kønsperspektiv. Samtidig bærer de fleste af artiklerne præg af at ville beskrive kulturelle møder i en historisk, social og politisk kontekst, i håb om at kunne undgå kultur'fæelden' og andetgørelse.

Artiklerne er ligeledes kendetegnet ved et opgør mod at konstruere og rekonstruere dikotomier angående islam i Vesten og sidde fast i ' $k ø n s$ og kultur-skruen' uden ende, uden kobling til andre elementer fra virkeligheden. Hermed lukkes kulturdebatten ikke, der sigtes derimod på at åbne for andre stemmer og andre vinkler der inkluderer sociale, historiske og politiske pro- 
blemstillinger - herunder migrationsmæssige vinkler på dette område.

"Der går et spøgelse gennem Europa" skrev Marx og Engels for 152 år siden i deres berømte Manifest. I dag er det et langt mere anderledes gespenst, der fra det kommunistiske poltergeist har ændret form til et kulturfundamentalistisk spøgelse, som nu vandrer gennem Europa. Et spøgelse der er vakt til live siden 1990ernes sammenbrud af verden opdelt i bi-polaritet mellem kommunismen og kapitalismen. En verden hvor vestlige samfundsproblemer blev anskuet og fortolket indenfor klassetænkning, og hvor etnicitet og religiøsitet hovedsageligt var antropologiske kuriøsiteter at finde "somewhere out there" blandt kulørte afrikanske stammer og eksotiske indianske folk.

Den strukturelle nyracisme lever i Danmark i bedste velgående på hverdagsplan, på arbejdsmarkedet og i den politiske lovgivning. Så meget at man forskellige steder i udlandet med undren ser på den blinde danske selvforherligelse og den populistiske omgang med de lange demokratiske traditioner.

Indenfor det seneste år har der i tyske og engelske medier været debatter om den danske håndtering af indvandrere og flygtninge. Allerede i 1997 skrev International Harald Tribune: "Der vokser et fremmedfjendsk ukrudt i Danmarks nysselige lille have" og ligeledes har kritiske røster lydt fra FNs komite for Økonomiske, Sociale og Kulturelle Rettigheder mod blandt andet den omstridte integrationslov. Røster fra forskellige sider af det politiske spektrum i Danmark hævder, at der er tale om en 'kulturkamp'. De baserer sig ofte på forestillinger om kultur og religion som uforanderlige størrelser og med "Danskheden" som det ypperste mål. Hvad det så end måtte være. Ligeledes anskues islam som en 'før-moderne' kvindeundertrykkende religion, og muslimer er derfor mere eller mindre uintegrerbare i den danske velfærdsstats lyksagligheder. Tankegange, som florerer på bedste vis langt ind i de ministerielle rækker og i det politiske liv, hvor debatter om køn og kultur spiller en central rolle (Hussein et al. 1997).

Køn og kultur lanceres desværre ofte som essentialistiske størrelser og ikke som konstruerede markører i komplekse samspil mellem forskellige handlinger og strategier. Et af problemerne i indvandrerdebatten er den ensidige fokusering på religion og kultur som værende årsagen til manglende deltagelse i det danske samfunds systemer og netværk. Dermed negligeres samfundets stigmatisering og medvirken til at skabe en ny underklasse, som ikke kun er udelukket fra et system og et netværk, men fra flere på en gang (Wikan, 1996).

At ville drkke temaer som køn, islam og orientalisme på en fyldestgørende måde indenfor et enkelt temanummer, kan synes vanvittigt ambitiøst. Hensigten har da også været at præsentere dele fra den nyere forskning, samt debatindlæg fra den mere visionære del af den politiske arena.

Vi begynder med en artikel om populærorientalisme af etnologen Magnus Berg, som analyserer Betty Mahmoodys "bestseller" bog: Ikke uden min Datter. Artiklen søger at forklare hvorfor denne bog og den senere filmatisering blev en ren block-buster i Vesteuropa. Magnus Berg konstruerer udfra traditionelle orientalisme-teorier et anderledes teoretisk udgangspunkt og anskuer Vestens konstruktion af Orienten som en måde at håndtere kulturel ambivalens på. Triviallitteratur behandles generelt ikke af orientalismeteoretikere som Edward Said, men kulturteoretisk set har triviallitteraturen samme kulturelle funktion, og Magnus Berg relaterer den orientalistisk triviallitteratur til nutidige kulturelle dispositioner herunder modernitet. Det bliver derved forståeligt, hvorfor Betty Mahmoodys bog blev så populær, men det påpeges samtidig, at denne særlige form for projicering ikke er uskyldig, men har ganske alvorlige konsekvenser, for dem der får den entydigt ne- 
gative og onde rolle, det værende såvel $\mathrm{i}$ forhold til køn som etnicitet.

I de følgende artikler fastholdes blikket på Vesten i det historiske møde med Øst.

Historiker Morten Thing historiserer i artiklen Jøden og orientaleren begrebet "orienten" og "orientalere" med udgangspunkt i anti-feministiske og anti-semitiske værker fra 1800tallet og påpeger at disse begreber om orienten er konstant foranderlige. I 1800tallets europæiske videnskabelige og skønlitterære værker fremstod blandt andet jøder som Europas "andre". Jøderne var Vestens indre "orientalere". Det er for Morten Thing, nationalismen der her er på spil, et forestillet fælleskab baseret på udskillelsen af andre, som ikke hører til nationalstaten. Ligeledes fremhæves køns- og racediskussioner baseret på anti-feministen og anti-semitten Otto Weiningers værk fra 1903, som en modernitets-kritik, moderniteten her forstået som en angst for kvinder og jøder, som begge blev forbundet med opfattelsen af det moderne.

Anna Rebecca Kledal bevæger sig ligeledes i det historiske rum og kobler dansk 1800tals orientalisme sammen med nationalromantiske strømninger.

Moder Danmark blandt haremskvinder fokuserer på den polsk-danske kunstmalerinde Elisabeth Jerichau-Baumann og hendes "orientalske" rejser i midten af 1800tallet og hendes adgang til osmanniske aristokrater. Betragtninger heraf belyser nye aspekter af det historiske forhold mellem Øst og Vest. Den post-koloniale tilgang til orientalisme begrebet kommer derfor i en dansk kontekst til kort og forfatteren mener at det i langt højere grad må kobles sammen med kønsmæssige og national liberale diskussioner.

De efterfølgende artikler vender blikket væk fra Vestens selvopfattelse i mødet med “Orienten”, og søger at finde nye måder at håndtere "orientalismen" på når de "Andre" studeres.

I De nogne kvinder $i$ hammam: Paradis eller helvede? er udgangspunktet er for reli- gionshistoriker Kate $\varnothing$ stergaards artikel om muslimske kvinder i hammam, som er offentlige badehuse. Scenariet er nutidige badehuse i Casablanca, Marokko. Pierre Bourdieus praktik-teori foreslås som teoretisk redskab til i højere grad at se på handlinger udfra forskellige interesser og strategier, end essentialistiske tilgange til religion.

Hammam i Casablanca er i vid udstrækning en praksis og nødvendighed blandt fattigere dele af befolkningen og forfatterens tese er, at badehusene fungerer som en slags antirum - en slags Gudløst rum - i forhold til den almindelige kulturelle orden. Samtidig og måske netop derfor er hammam et diskussionspunkt $\mathrm{i}$ forhold til det at være kvindelig muslim. Det kan fungere som et socialt mødested for kvinder og det legitimeres som religiøst fortjenstfuldt, idet renselse er en af de fundamentale religiøse pligter. Omvendt kan skamløsheden som badehusene er forbundet med - ifølge visse teologiske tekster - være særligt belastende for kvinder, hvorfor de ved at fravælge det, kan opnå en stærkere position.

Vi befinder os i næste artikel af religionshistoriker Catharina Raudvere stadig i Mellemøsten, og har igen fokus på kvinder og religiøse praksisser. Med udgangspunkt i globaliseringsteorier og det sen-moderne samfund analyseres politisk aktive muslimske kvinders handlerum og indflydelse i det politiske liv i det nutidige Istanbul, Tyrkiet. Udover at gøre op med muslimske kvinders tildelte offerrolle, understreger forfatteren dobbeltheden i politiseringen af islam. Dette giver både øget råderum for ageren, men ligeledes nye begrænsninger kvinder og de nye politiske bevægelser imellem. Det er ikke entydige bevægelser, og moderniteten indebærer ikke traditionens død, men snarere muligheder for at vælge blandt forskellige traditioner.

Migrationsforsker Ninna Nyberg Sørensen analyserer i sin artikel Mond, migration og byrum $i$ grenselandet mellem Spanien og Marokko, hverdagseffekten af den spanskmarokkanske grænse set i lyset af statsmagt 
og "mobile livsstrategier". Det historiske perspektiv inddrages, som modvægt mod forestillinger om en akut og ensidig migrationskrise i Vesteuropa og de deraf følgende øgede politiske stramninger. Mahgreb-landene, som er det nordlige Afrika, er kendetegnet ved lange traditioner for kontinuerlige migrationsbevægelser af mennesker fra begge sider af henholdsvis det europæiske og det afrikanske kontinent. Artiklen tager udgangspunkt i migration som det er erfaret af tre marokkanske mænd. Nyberg Sørensen etablerer en tese om grænseland og at grænser oftest er udflydende i kulturel forstand - og falder ikke nødvendigvis sammen med nationalstatens grænser. Dette făr ligeledes betydning for opfattelser af maskulinitet.

I de sidste to artikler flyttes fokus fra de mere kulturanalytiske tilgange til diskussioner om politiske rettigheder for religiøse samfund i Vesten, herunder også Danmark.

Artiklerne problematiserer og påpeger nødvendigheden af diskussioner om ændringer i lovgivningen og accepten af det fler-kulturelle og det fler-religiøse samfund og hvilke kønsmæssige implikationer det har.

Hvad er rimelige grænser for religionsfriheden og hvad er almindelig intolerance mod eksempelvis islam i Danmark? Og hvorledes kan samfundet styrke og højne retsikkerheden for indvandrere og flygtninge af begge køn?

Artiklen Muslim and South Asian Women af jurist Samia Bano viser et eksempel på hvorledes man i et andet EU-land, England, håndterer og accepterer et fler-kulturelt samfund. Samia Banos artikel viser at dette ikke er uden kvaler og problematiserer den engelske lovgivnings accept af sædvanelov indenfor forskellige religiøse minoriteter og den betydning det kan have for kvinder. Hvem kan og hvem skal bestemme på den religiøse og/eller kulturelle minoritets vegne, er spørgsmål som heller ikke er uvæsentlige i en dansk sammenhæng.
Cand.polit Naser Khader kontekstualiserer denne diskussion i forhold til ændringer i Grundloven, til både at afspejle samfundets forandrede sammensætning i retning mod det fler-kulturelle, men understreger samtidig nødvendigheden af at bevare den individorienterede lovgivning, hvor kønsperspektivet ligeledes inddrages. Der diskuteres op imod den engelske lovgivningspraksis om hvorvidt kulturelle og religiøse rettigheder skal indskrives i lovgivningen, eller om Grundloven i en dansk sammenhæng skal sikres så den kan danne grund. Et fundament der netop konstituerer danskheden.

Vi afrunder temanummeret med adskillige debatartikler om tørklæder og fantasier om danskhed, og sætter forløbigt punktum for årets stafetdebat angående kvinde og -køns navnestrategier.

Vi håber med dette temanummers artikler og debatindlæg, at sende bolden videre til at inddrage etnicitets perspektiver på kønsdebatten. Redaktionen har tidligere beskæftiget sig med temanumre om køn og etnicitet (Kolonialisme/postkolonialisme 1996, Køn og etnicitet 1998), og ser dette temanummer som en udbygning af de tidligere debatter. Endvidere håber vi at artiklerne, i dette nummer af Kvinder, Køn \& Forskning, kan bruges udenfor akademia og være medspiller i diskussionerne om "de Andre" kvinder og mænd i Danmark.

En tak til alle bidragydere i dette temanummer.

Temaredaktør Anna Rebecca Kledal

\section{LITTERATUR}

. Wikan, Unni (1996) Mot en ny norsk underklasse? Indvandrere, kultur og integrasjon. Gyldendal, Norsk Forlag, Oslo.

- Hussein, M. et al (1997) Medierne, minoriteterne og majoriteten. Nævnet for Etnisk Ligestilling. Indenrigsministeriet. 